Discussion Paper No. 09-022

Is There a Trade-Off Between Academic Research and Faculty Entrepreneurship?

Evidence from U.S. NIH Supported Biomedical Researchers

Dirk Czarnitzki and Andrew A. Toole

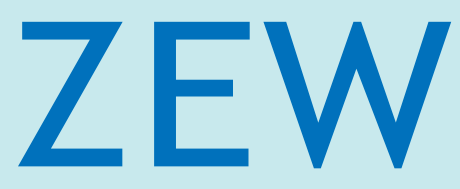

Zentrum für Europäische Wirtschaftsforschung $\mathrm{GmbH}$

Centre for European

Economic Research 
Discussion Paper No. 09-022

\section{Is There a Trade-Off Between Academic Research and Faculty Entrepreneurship? Evidence from U.S. NIH Supported Biomedical Researchers}

Dirk Czarnitzki and Andrew A. Toole

Download this ZEW Discussion Paper from our ftp server:

ftp://ftp.zew.de/pub/zew-docs/dp/dp09022.pdf

Die Discussion Papers dienen einer möglichst schnellen Verbreitung von neueren Forschungsarbeiten des ZEW. Die Beiträge liegen in alleiniger Verantwortung der Autoren und stellen nicht notwendigerweise die Meinung des ZEW dar.

Discussion Papers are intended to make results of ZEW research promptly available to other economists in order to encourage discussion and suggestions for revisions. The authors are solely responsible for the contents which do not necessarily represent the opinion of the ZEW. 


\section{Non-technical Summary}

This paper contributes to the debate whether academic scientists benefit from industry experience with respect to their academic research productivity as measured by publication outcome. One strand of the literature argues that university faculty members who found or join firms may actually become more productive in terms of the quantity and quality of their

publications. Although the underlying mechanisms remain unclear, these entrepreneurial faculty members may be leveraging private sector sources for additional research funding, expanded laboratory facilities, or larger research teams.

Another strand of the literature takes the opposite perspective and argues that university faculty members who found or join firms trade-off academic research productivity. This alternative perspective draws on both firm-level and individual-level arguments. At the firm-level, several empirical studies identify a trade-off between a firm's science-orientation and its innovative performance. These studies cast doubt on the belief that cutting-edge research aimed at extending scientific knowledge can be fruitfully pursued in the for-profit sector, at least in the longer term. At the individual-level, a faculty member's choice to found or join a for-profit firm obligates him or her to perform many new and varied commercialization activities. It is argued that these activities divert significant time and cognitive efforts away from research aimed at extending public scientific knowledge and impose a cost on academic knowledge accumulation in the not-for-profit research sector.

Using a long panel of NIH supported U.S. biomedical scientists, we find that academic scientists who eventually choose to commercialize their research results are more productive during their career in academe than a randomly selected control group. At the point in time when the scientists choose to leave academe, however, their publication record drops. We break the scientists into three groups after their initial commercialization decision: academic entrepreneurs that do not return to academe, others that either leave only partly to 
industry or return after gathering some industry experience, and those where we were not able to surely determine their career status after their initial commercialization choice. This yields interesting insights. Academic entrepreneurs never achieve as high publication records as they did before commercializing. However, the scientists that leave only partly or return to academe, perform equally well as scientists from the control group that did not commercialize. The other groups that leave permanent or where the status remains unknown publish less than the control group while or after commercializing. 


\section{Das Wichtigste in Kürze (Summary in German)}

Diese Studie untersucht, wie sich die Produktivität von Wissenschaftlern an Universitäten durch Erfahrungen aktiver Mitarbeit in Firmen verändert. Die Produktivität wird dabei durch Publikationen in referierten Fachzeitschriften gemessen. Die Literatur zum Thema argumentiert einerseits, dass Erfahrungen aus der Wirtschaft zu einem akademischen Produktivitätszuwachs im Hinblick auf Anzahl der Publikationen und deren Qualität führen können. Während die genauen Mechanismen dabei nicht eindeutig belegt sind, könnte ein Grund sein, dass ein Wissenschaftler durch Tätigkeiten in der Privatwirtschaft mehr Forschungsmittel zur Verfügung hat und diese auch effizient einsetzt, z.B. zum Ausbau der eigenen Forschungsgruppe im Hinblick auf Personal und Ausstattung.

Andererseits gibt es Studien, die eine gegenteilige Meinung vertreten. Wissenschaftler, die eine Firma gründen oder die Hochschulen (teilweise oder permanent) verlassen, sehen sich einem „trade-off“ zwischen privatwirtschaftlicher und akademischer Produktivität gegenüber. Diese konkurrierende Sichtweise wurde in empirischen Studien sowohl auf der Firmen- als auch auf der Personenebene belegt. Auf der Firmenebene stehen sich die wissenschaftliche Ausrichtung des Unternehmens und der (kurzfristige) Innovationserfolg entgegen. Diese Studien bezweifeln, dass „State of the Art“ Grundlagenforschung in der Privatwirtschaft - zumindest langfristig - ebenso erfolgreich wie in Hochschulen betrieben werden kann. Auf der Personenebene wird der zeitliche „trade-off“ zwischen Forschungs- und verschiedenen Managementtätigkeiten diskutiert. Es wird argumentiert, dass letztere signifikante Zeit des Wissenschaftlers sowie kognitive Anstrengungen erfordern, die von fundamentaler Forschungsaktivität ablenken.

Unter Verwendung einer Längsschnittdatenbank amerikanischer Wissenschaftler im Feld der Biowissenschaften zeigt sich, dass Professoren, die ihre Forschungsergebnisse an 
einem späteren Zeitpunkt ihrer Karriere kommerzialisieren, produktiver sind als eine zufällig gezogene Kontrollgruppe von Professoren, die ihre Forschung nicht kommerzialisieren. Zum Zeitpunkt der Entscheidung, die Hochschulen zwecks einer Karriere in der Industrie zu verlassen, sinkt die Publikationsproduktivität erwartungsgemäß. Jedoch zeigt sich auch, dass jene Wissenschaftler, die später an eine Hochschule zurückkehren nicht produktiver sind als zuvor. Stattdessen trifft das Gegenteil zu. Während die akademischen Unternehmer in ihrer Zeit an der Universität vor der Kommerzialisierungsentscheidung produktiver waren als eine Kontrollgruppe von anderen Professoren, erreichen sie nach ihrer Rückkehr kein vergleichbares Niveau. Die Produktivität unterscheidet sich nicht mehr signifikant von der Kontrollgruppe. 


\title{
Is there a trade-off between academic research and faculty entrepreneurship? Evidence from U.S. NIH supported biomedical researchers ${ }^{1}$
}

\author{
Revised version is forthcoming in \\ Economics of Innovation and New Technology \\ Dirk Czarnitzki ${ }^{\mathrm{ab}, \mathrm{c}}$ and Andrew A. Toole $\mathrm{d}^{\mathrm{d}, \mathrm{c}}$ \\ a) K.U.Leuven, Dept. of Managerial Economics Strategy and Innovation, Leuven (Belgium) \\ b) Steunpunt O\&O Indicatoren at K.U.Leuven \\ c) Centre for European Economic Research (ZEW), Mannheim (Germany) \\ d) Rutgers University, New Brunswick, NJ (United States)
}

April 2009

\begin{abstract}
Is there a trade-off of scholarly research productivity when faculty members found or join for-profit firms? This paper offers an empirical examination of this question for a subpopulation of biomedical academic scientists who received research funding from the U.S. National Institutes of Health (NIH). In this study, we are able to distinguish between permanent versus temporary employment transitions by entrepreneurial faculty members and examine how their journal article publication rates change using individual-level panel data. We find that the biomedical scientists who eventually choose to found or join a for-profit firm were more productive during their careers in academe than a randomly selected control group of their NIH peers. When they pursue entrepreneurship in the private sector, however, their scholarly productivity falls. Those entrepreneurial faculty members who return to academe are not as productive as they were before their entrepreneurial experience in terms of journal publications.
\end{abstract}

Keywords: $\quad$ academic entrepreneurship; SBIR; NIH; biomedical research; life scientist productivity

JEL-Classification: O38; O31; L53

\footnotetext{
${ }^{1}$ We thank the participants of the conference "The Labour Market for Scientists and Engineers”, University of Maastricht (May 2008), and two anonymous referees as well as the editor for valuable comments. This research benefited from financial support by the Marian Ewing Kauffman Foundation, Kansas City, and by the National Bureau of Economic Research (NBER), Cambridge.
} 


\section{Introduction}

How is research productivity affected when academic scientists pursue commercialization activities in the private sector? There is an emerging debate in the scholarly literature on this question. One strand of the literature argues that university faculty members who found or join firms may actually become more productive in terms of the quantity and quality of their publications (Zucker and Darby, 2007, Lowe and GonzalezBrambila, 2007). Although the underlying mechanisms remain unclear, these entrepreneurial faculty members may be leveraging private sector sources for additional research funding, expanded laboratory facilities, or larger research teams.

Another strand of the literature takes the opposite perspective and argues that university faculty members who found or join firms trade-off academic research productivity. This alternative perspective draws on both firm-level and individual-level arguments. At the firm-level, several empirical studies identify a trade-off between a firm’s science-orientation and its innovative performance (Gittelman and Kogut, 2003, Stern, 2004, Toole and Czarnitzki, 2008). These studies cast doubt on the belief that cutting-edge research aimed at extending scientific knowledge can be fruitfully pursued in the for-profit sector, at least in the longer term. At the individual-level, a faculty member's choice to found or join a for-profit firm obligates him or her to perform many new and varied commercialization activities. It is argued that these activities divert significant time and cognitive efforts away from research aimed at extending public scientific knowledge and impose a cost on academic knowledge accumulation in the not-for-profit research sector (Toole and Czarnitzki, 2009).

This paper contributes to the emerging debate by examining how permanent versus temporary employment transitions to for-profit firms affect individual-level academic 
research productivity. ${ }^{2}$ Given the possibility of leveraging private sector resources, those academic scientists who return to the university may enjoy increased research productivity while those who never return may simply follow a new career path in the private sector where publication is less important.

The rest of the paper proceeds as follows. The next section provides a brief overview of the prior literature examining the trade-off between faculty entrepreneurship and academic research productivity. Section 3 discusses the data and shows descriptive statistics while section 4 presents the regression results. Concluding remarks are in section 5.

\section{Faculty entrepreneurship and Individual-level Research Productivity}

In an early contribution to the literature, Louis et al. (1989) recognized that that the phrase "faculty entrepreneurship" encompasses a number of non-traditional faculty behaviors. Their topology orders different entrepreneurial behaviors by the degree to which they are incompatible with a traditional view of the academic scientist's role. Building on their work, an alternative topology ranks the different entrepreneurial behaviors by the degree to which they involve the faculty member's time, cognitive effort, and commitments to organizations outside the non-for-profit research environment. Behaviors such as seeking external grants, disclosing inventions, and seeking patent protection appear at the low end of this effort-commitment spectrum. Collaboration activities with for-profit firms for research or invention, consulting arrangements, or memberships on advisory boards would appear toward the middle of this spectrum. Forming a new company or joining an existing for-profit firm would be at the high end of this spectrum since these behaviors involve significant time,

\footnotetext{
${ }^{2}$ Our prior work showed an economically and statistically significant decrease in journal publications, weighted journal publications, and the value of research grant awards from the U.S. National Institutes of Health after academic biomedical scientists founded or joined firms. In that work, however, we were unable to split our sample of academic entrepreneurs into those who left academic research permanently and those who returned to the university after a temporary excursion into the private sector.
} 
cognitive effort, and external commitments. ${ }^{3}$ All of these forms of faculty entrepreneurship have the potential to enhance or detract from a faculty member's scholarly productivity. However, behaviors at the high end of this spectrum are more likely to require a trade-off of academic research productivity. In this paper, we focus on the more extreme faculty entrepreneurial behaviors of founding or joining a for-profit firm.

Our literature search identified only three other empirical studies (besides our own prior work) that focused specifically on how founding or joining a for-profit firm affects academic research productivity. The bulk of the literature is focused on whether faculty invention disclosures or patenting activity enhance or detract from scholarly research productivity. Overall, these studies find that invention disclosures and patenting enhance and complement scholarly productivity. ${ }^{4}$ Consequently, there does not appear to be a costly trade-off of academic research productivity when faculty members engage in these forms of faculty entrepreneurship. However, since invention disclosures and patenting are at the low end of the faculty effort and external commitment spectrum, generalizing this finding to all other entrepreneurial behaviors would be inappropriate.

Lowe and Gonzalez-Brambila (2007) is the first econometric study that examined how founding or joining a for-profit firm affects academic research productivity. They analyzed a sample of 150 faculty entrepreneurs who founded firms between 1990 and 1999 representing fourteen U.S. research universities and one national laboratory. All of these individuals started their companies based on inventions previously disclosed to their institution's technology transfer office and maintained full-time faculty appointments. Of the 150 faculty entrepreneurs, 77 were in engineering fields, 60 were in medicine and biology, and 13 were in chemistry.

\footnotetext{
${ }^{3}$ In the event that an entrepreneurial faculty member decides to make a permanent transition to the for-profit sector, faculty entrepreneurship becomes a complete employment transition.

${ }^{4}$ See Breschi et al. (2008), Czarnitzki et al. (2009), Azoulay et al. (2006), and Goldfarb et al. (2009) and the references therein. When patenting takes place with corporations, Czarnitzki et al. (2009) find that faculty patenting detracts from publications and citations.
} 
To test for publication productivity differences, they defined an "entrepreneurship" dummy variable that took the value of zero in the years prior to the faculty member starting the firm and the value of one thereafter. They combined their sample of academic entrepreneurs with matched control groups composed on their graduate school peers and their coauthor peers. Using annual publications for the period 1970 through 2004 and a negative binomial regression model, they found mixed results across fields. For engineering, the entrepreneurship dummy was positive and significant at a $1 \%$ level indicating that faculty entrepreneurs publish significantly more than the control group in the years after starting their firm. For chemistry and the combined fields of medicine and biology, however, the entrepreneurship dummy was not significantly different from zero. They concluded, based on their full sample, that "the potential cost of sacrificing academic research is not significant if even existent” (Lowe and Gonzalez-Brambila 2007, p. 193).

Zucker and Darby (2007) identified a sample of 327 “star” scientists based on genesequence-discovery articles published through 1989 and listed in Genbank, an international scientific database. Using information from the Science Citation Index, they identified 207 of these stars as having published with a U.S. institutional affiliation and further used the article’s address information provided for the “corresponding” author to allocate these individuals into three groups: affiliated, linked, and untied. Twelve of their stars were categorized as affiliated, which means at least one of their articles showed them as having an address at a private firm. Fifty-seven of their stars were categorized as linked, which means at least one of their articles showed them as having a coauthor with an address at a private firm. The remaining 138 stars were categorized as untied, which means that none of their articles showed a corresponding author who had an address at a private firm.

Based on these data, Zucker and Darby showed descriptive statistics and regression results intended to examine how involvement of star scientists with private firms influenced 
both the quantity and quality of their journal publication output. Relative to untied stars, their descriptive statistics show that both affiliated and linked stars published more articles per year, had more citations per year, and had larger stocks of total citations. For their regression analysis, they further differentiated linked stars into regionally local and non-local groups based on the U.S Bureau of Economic Analysis definition of functional economic areas. For each of the groups of stars, the affiliated stars and the two regional groups of linked stars, they created time period dummy variables for articles which corresponded to when they observed the address information for the private firm: before firm association, during firm association, and post firm association. Using weighted regressions, they analyzed how articles per year and citations per year depend on these nine dummy variables with untied stars as the base group. They interpreted their regression results as indicating that "the involvement of the stars with firms also increases their scientific research with no decrement or even an actual increase in its impact [based on citations]” (Zucker and Darby 2007, page 460).

Buenstorf (2009) examined how four indicators of entrepreneurial behavior influenced the quantity and quality of publications for a sample of elite German scholars who held director positions at the Max Planck Institute over the period 1985-2004. The four indicators roughly capture the progression of faculty entrepreneurial behaviors from the low end to the high on the effort-commitment spectrum described above. The entrepreneurial behaviors examined were: disclosing inventions, disclosing inventions that were licensed to the private sector, disclosing inventions that were licensed to spin-off companies, and becoming a founder of a spin-off company. ${ }^{5}$ For the biomedical, chemistry, physics, and technology divisions of the Max Plank Institute, there were a total of 140 entrepreneurial directors who disclosed at least one invention in the sample period. Of these, only 34 were

\footnotetext{
${ }^{5}$ In his sample, the German scholars who were listed as founders of a spin-off did not participate in the operations and management of the company. Presumably, they participated in research projects at the spin-off, but there is limited information about the founder's involvement.
} 
subsequently observed as spin-off founders. As one would expect, these data suggest that founding a spin-off is a relatively rare event.

Using a control group of other Max Planck directors from the same divisions who did not disclose any inventions, Buenstorf found that the most extreme entrepreneurial behavior, being a founder of a spin-off, affected academic research productivity differently than the other behaviors. To model permanent productivity differences due to these alternative behaviors, four dummy variables were created that each took the value of zero in the years prior to the observed behavior and the value of one thereafter. Using a fixed effects method, both with and without probability weights, the results indicate that Max Planck scholars significantly increased publications and citations after they disclosed at least one invention. ${ }^{6}$ They significantly increased publications and citations after they disclosed at least one invention that was licensed to a private firm. This indicator included patented inventions. For licensing to spin-offs, the regression results were mixed. The coefficient estimates were mostly insignificant, but they were generally positive. In contrast and most relevant to the current analysis, Buenstorf found that the number of publications and citations to Max Planck scholars significantly decreased after they became founders of a spin-off company. Buenstorf's results are consistent with prior research suggesting that entrepreneurial behaviors on the low end of the effort-commitment spectrum are complementary to academic publication and citations, but his results also suggest a trade-off emerges when faculty members found a spin-off firm.

\footnotetext{
${ }^{6}$ This paragraph summarizes his main results appearing in tables 4, 5, and 6 of Buenstorf (2009). Table 7 attempts to get at marginal differences between each of the entrepreneurial behaviors, but these results are limited by the small sample size and multicollinearity.
} 


\section{Data and Methods}

\subsection{Database construction}

Perhaps the greatest barrier to research on the relationship between faculty entrepreneurship and academic research productivity is the paucity of systematic data identifying and tracking academic scientists as they engage in entrepreneurial behaviors. There are essentially two big challenges in this regard. The first challenge is to define and identify the population of academic researchers. For most countries, and this is certainly true for the U.S., there is no source of information that identifies the complete population of academic researchers, even if one focuses on a specific field and a specific point in time. To address this challenge in our work, we focused on a large and interesting subpopulation: biomedical academic researchers in the fields of biology, chemistry, and health sciences who were principal investigators (PIs) on at least one research award from the U.S. National Institutes of Health (NIH) between 1972 and 1996. Our population of academic researchers contains about 61,000 individuals. In what follows, our statistical analysis will allow inference for this subpopulation of academic researchers. Any generalization beyond this subpopulation is not statistically legitimate because we cannot say with confidence that our subpopulation is representative of the larger population of all academic researchers.

The second challenge is to observe the entrepreneurial behaviors of the academic researchers in the population. Unlike patent statistics that can be obtained on electronic media from government agencies, there is no institution (governmental or otherwise) that systematically tracks the other forms of faculty entrepreneurship for the entire population, or even for our subpopulation of biomedical academic researchers. ${ }^{7}$ For this analysis, we would like to know who in the population has founded or joined a for-profit firm. Because this is a

\footnotetext{
${ }^{7}$ In principle, at least some of this information can be collected from the subset of public research institutions that have technology transfer offices, but this still requires negotiation about privacy issues and a survey instrument. This limitation is the reason most research papers in this literature focus on a singe institution such as Stanford University, Massachusetts Institute of Technology (MIT), Max Planck, and so forth.
} 
rare event, standard random sampling methods will not provide enough observations to allow for statistical analysis. Following Stuart and Ding (2006), we used a case-cohort sampling design. To implement this method, we used information from the U.S. Small Business Innovation Research (SBIR) program to obtain systematic data on academic scientists who founded or join for-profit firms. These “cases” were grouped into cohorts and a stratified random sample was drawn from the population to form a control group for the statistical analysis (see Toole and Czarnitzki 2008b for more details on how the sample was obtained).

Using the SBIR program to identify those academic scientists who found or join forprofit firms has both advantages and disadvantages. ${ }^{8}$ The overarching advantage is that the SBIR program is the only public source of systematic information on new and small firms in the U.S. that identifies the individuals involved in the firm's research. Without this information, it would be impossible to conduct the analysis. The second advantage is that the academic scientists who are leading the firm’s research have committed a non-negligible quantity of effort to the for-profit firm. According to the stated SBIR guidelines, these individuals certified that they spent at least $51 \%$ of their time at the for-profit firm at the time of SBIR award and throughout the duration of the project(s). This helps to assure us that we analyzing "real” efforts by academic entrepreneurs. The main disadvantage is that the SBIR program is only one source of startup capital used by faculty entrepreneurs who found or join for-profit companies. If entrepreneurial faculty members did not get financial support from the SBIR program, they will not show up in our data. This limitation suggests we are undercounting the actual number of biomedical academic researchers who found or join forprofit firms.

To analyze how permanent versus temporary employment transitions to the private sector affect academic research productivity, we use a scientist-level panel database with

\footnotetext{
${ }^{8}$ See Toole and Czarnitzki $(2007,2008)$ for more information on the SBIR program and its role in the data construction process.
} 
information on annual journal publications for the period 1976 through 2003. From the SBIR information, we identified 213 academic entrepreneurs in the NIH subpopulation who founded or joined a for-profit firm between 1983 and $1996 .^{9}$ These individuals were allocated into fifteen cohorts based on the specific NIH institute that sponsored their academic research such as the National Cancer Institute, the National Eye Institute, and so forth. Across all cohorts, we drew a total random sample of 1,500 NIH research peers from our population. These individuals serve as the comparison or control group. This group is composed of "traditional” NIH supported biomedical researchers who did not found or join a for-profit firm. ${ }^{10}$

For the empirical analysis, we also required information on these scientists’ degree years, degree institutions, and journal publication histories. We used the UMI Proquest Dissertation database and Internet searches to gather the degree information while the journal publication data were collected from the MEDLINE database using the Publication Harvester described in Azoulay et al. (2006). The final sample consists of 447 biomedical academic scientists who received their Ph.D. or M.D. degrees between 1965 and 1991. Seventy-seven of these individuals are academic entrepreneurs who founded or joined for-profit firms. ${ }^{11}$

To determine whether the SBIR employment transitions for the academic entrepreneurs were permanent or temporary, we performed Internet searches based on the scientist's name, affiliation, and location. This allowed us to define three subgroups of academic entrepreneurs: those who returned to the university, those who stayed in the private sector, and those whose subsequent employment could not be determined. For academic entrepreneurs who returned to the university, we calculated their total time spent in the

\footnotetext{
${ }^{9}$ The SBIR program was established in 1982 and its first awards were in 1983.

${ }^{10}$ Because we are analyzing a relatively rare form of faculty entrepreneurship, the likelihood that a member of our randomly selected control group founded or joined a for-profit firm through a non-SBIR route is extremely small.

${ }^{11}$ To date, this is the largest sample of biomedical academic researchers who founded or joined for-profit firms to be analyzed in the literature.
} 
private sector through 2004 using their SBIR project start and end dates available online through the NIH Computer Retrieval of Information on Scientific Projects (CRISP) database.

\subsection{Variables and descriptive statistics}

We analyzed two measures of academic research productivity in this paper. The first, journal publications per year $(P U B)$, is a traditional measure. The second, annual journal publications divided by coauthors (PUBW), is motivated by the possibility that laboratory size may influence the scientist's annual number of journal publications.

Our main explanatory variables identify academic entrepreneurs $(A E)$ in different career stages using dummy variables. An $A E$ is an NIH supported academic biomedical researcher who is subsequently observed as a PI on an SBIR commercialization grant. This is defined to be his or her first date of faculty entrepreneurship behavior involving the founding or joining of a for-profit firm. We refer to this as the first date of their "entrepreneurial activity" in this paper. The control group of randomly selected NIH research peers serves as the reference category. The variable $A E \_I N$ is a dummy variable that equals one while the biomedical researcher is active in academe and switches to zero at the first date of his or her entrepreneurial activity. Its complement, $A E \_O U T$, is a dummy variable that equals zero while the scientist is active in academe and switches to one at the first date of his or her entrepreneurial activity and always stays equal to one from that point forward in time.

Using the newly collected information on the current employment status of academic entrepreneurs, we are able to partition the $A E \_O U T$ indicator into three separate employment transition states: permanently out of academe, temporarily out of academe, and unknown. For those AEs who never returned to academe, we define a dummy variable, $A E \_P E R M$, which switches from zero to one at the first date of their entrepreneurial activity. This dummy variable stays equal to one for the remaining periods in our sample. Out of the 77 academic entrepreneurs, 25 leave academe permanently. For those AEs who eventually 
returned to academe, we define a dummy variable, $A E \_T E M P$, which switches from zero to one at the first date of their entrepreneurial activity. This dummy variable identifies those scientists who commercialized through the SBIR program once or multiple times, but kept either a part-time position as faculty or returned to a university after having worked in a company for the duration of the SBIR project. Out of the 77 academic entrepreneurs, 28 leave academe temporarily. For the unknown status, we define a dummy variable, AE_UNKNOWN, which switches from zero to one at the first date of their entrepreneurial activity. This dummy variable stays equal to one for the remaining periods in our sample. Our data collection efforts could not determine whether these academic entrepreneurs ever returned to academe or stayed in industry for the remainder of their careers. We suspect that this lack of information reflects a permanent transition. Because we are not sure, we prefer to keep these scientists as a separate group in the analysis. There are 24 out of the 77 academic entrepreneurs in this group. Of course, all AE variables always equal zero for the NIH research peers in the control group.

Figure 1 shows the bivariate relationship between average publication counts per year by the different employment states. The peer group consists of faculty members that do not commercialize through the SBIR program throughout the whole period 1976 to 2003. On average, a peer group scientist publishes 2 journal articles per year. Academic entrepreneurs publish slightly more than the peer group during their careers in academe: 2.2 publications per year. When academic entrepreneurs leave academe, publications drop to about 1.5 per year. For those academic entrepreneurs who leave permanently, their average journal publications drop to one article per year. For those academic entrepreneurs who leave temporarily, average journal publications per year increase to 2.4 papers. Descriptively, it appears AEs who return to academe may be able to leverage their private sector experiences or connections to increase scholarly productivity. For the group AEs whose current 
employment status remains unknown, average journal publications per year is very similar to that of the scientists who leave permanently with 1.2 papers. This suggests that the majority of persons in the unknown status never returned to academe.

Figure 1: Average publication counts per year by career status

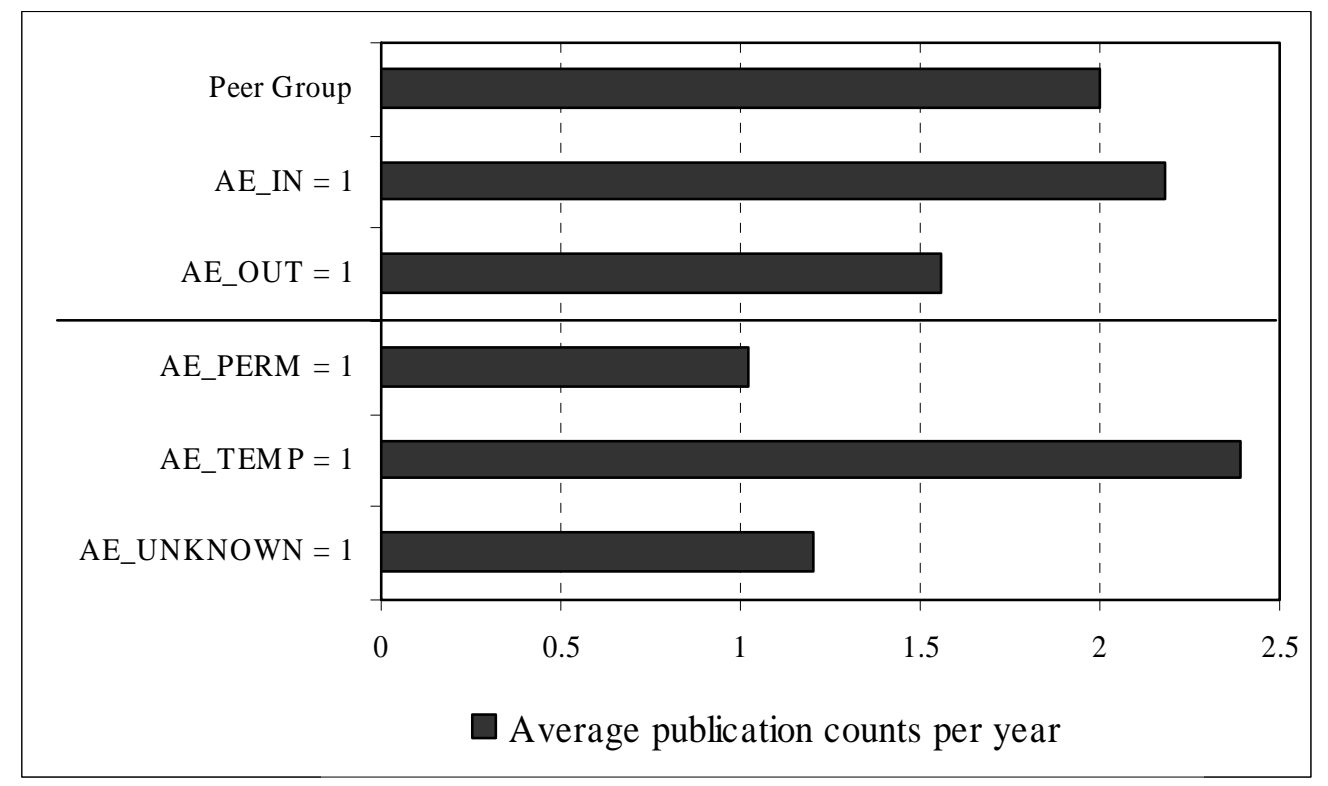

Figure 2 shows a very similar picture for weighted publications per year, which are divided by the number of coauthors. One interesting difference, however, is in the $A E \_T E M P$ status. Compared to $A E \_I N$ in Figure 2, these academic entrepreneurs publish less than they did prior to the first date of their entrepreneurial activity. This suggests that the increase average publications observed for those academic entrepreneurs with temporary employment transitions may be due to larger co-authorship networks. 
Figure 2: Average weighted publication counts per year by career status

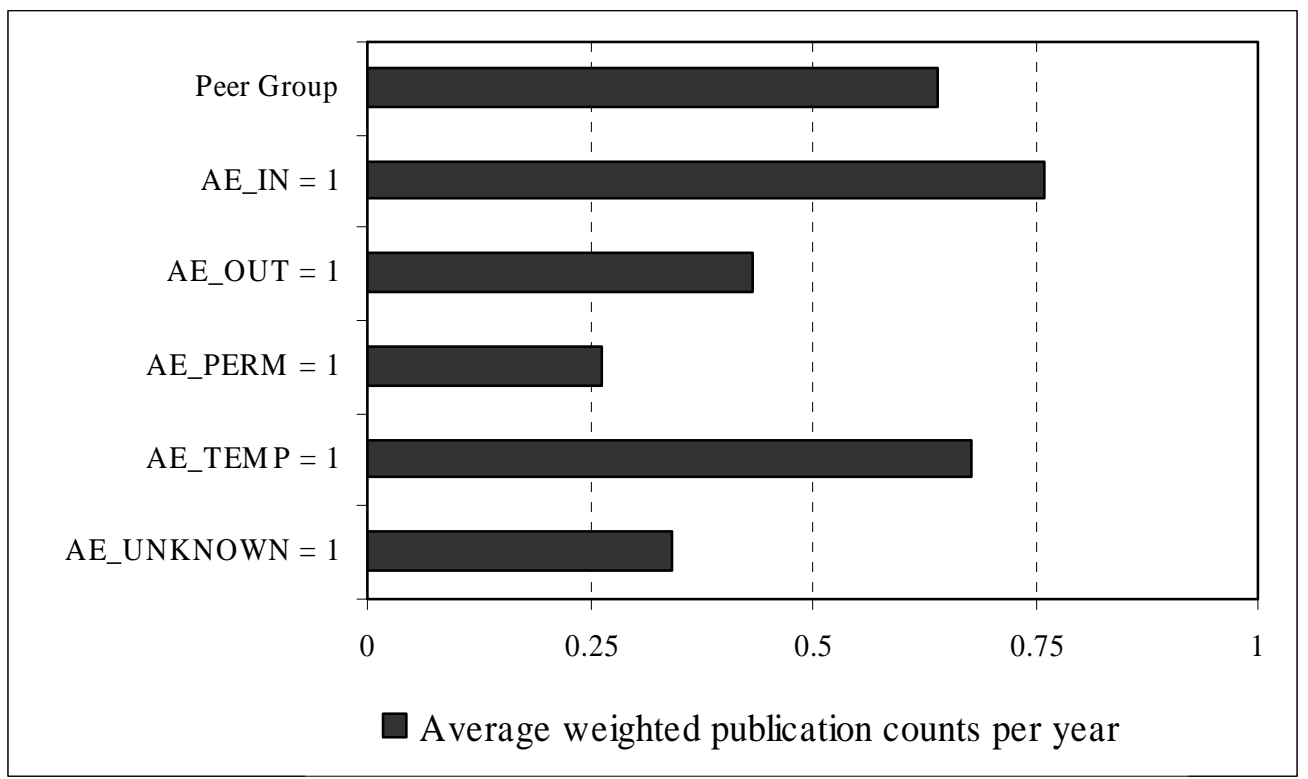

In the subsequent regression analysis we investigate whether these relationships hold, once we control for time effects (time dummies), age effects, and unobserved heterogeneity. In line with findings in the literature on life cycle productivity of scientists, we find it is important to control for age (see e.g. Diamond, 1986, Levin and Stephan, 1991). Rather than chronological age, we use a scientist's career age, which is defined to be the number years elapsed since their Ph.D. or M.D. degree. Following Stuart and Ding (2006), we assume a maximum career age of thirty-five years before retirement. Descriptive statistics of all variables used in the regression models are presented in Table 1. 
Table 1: Descriptive statistics

\begin{tabular}{|c|c|c|c|c|c|c|c|c|}
\hline \multirow[b]{2}{*}{ Variable } & \multicolumn{4}{|c|}{$\begin{array}{l}\text { Academic Entrepreneurs } \\
\qquad N=1961\end{array}$} & \multicolumn{4}{|c|}{$\begin{array}{c}\text { Control group } \\
N=8863\end{array}$} \\
\hline & Mean & Std. Dev. & Min & Max & Mean & Std. Dev. & Min & Max \\
\hline$P U B$ & 1.842 & 2.492 & 0 & 19 & 2.003 & 2.679 & 0 & 40 \\
\hline PUBW & 0.583 & 0.844 & 0 & 8.249 & 0.639 & 0.872 & 0 & 11.221 \\
\hline$A E \_I N$ & 0.459 & 0.498 & 0 & 1 & 0 & 0 & 0 & 0 \\
\hline$A E \_O U T$ & 0.540 & 0.498 & 0 & 1 & 0 & 0 & 0 & 0 \\
\hline$A E \_P E R M$ & 0.183 & 0.386 & 0 & 1 & 0 & 0 & 0 & 0 \\
\hline$A E \_T E M P$ & 0.190 & 0.393 & 0 & 1 & 0 & 0 & 0 & 0 \\
\hline$A E \_U N K N O W N$ & 0.168 & 0.374 & 0 & 1 & 0 & 0 & 0 & 0 \\
\hline CAREER AGE & 16.732 & 8.615 & 1 & 35 & 15.594 & 8.601 & 1 & 35 \\
\hline \multicolumn{9}{|c|}{ Alternative specification for the combination of AE_OUT and AE_TEMP in robustness test } \\
\hline AE_YEARS_OUT & 1.651 & 3.926 & 0 & 21 & 0 & 0 & 0 & 0 \\
\hline$A E \_B A C K$ & 0.149 & 0.356 & 0 & 1 & 0 & 0 & 0 & 0 \\
\hline
\end{tabular}

Note: Time dummies not presented. Sample covers the years from 1976 to 2003.

\section{Econometric Results}

\subsection{Journal Publications Per Year}

Our first measure of scholarly productivity is journal publications per year. As this is a positive integer variable, we estimate count data models using both a pooled Poisson quasimaximum likelihood (QML) estimator and a fixed-effects Poisson QML estimator. ${ }^{12}$ The advantage of pooled Poisson is that is does not impose the strict exogeneity assumption. In the pooled models, shocks to publications at time t are allowed to influence future values of the explanatory variables. Dependence over time is taken into account by clustering the standard errors at the individual scientist level. However, as is well known from the economics of science literature, unobserved heterogeneity across researches (i.e. their innate research "ability”) can be a source of productivity differences. We employ the following model of publications incorporating unobserved heterogeneity: ${ }^{13}$

$$
E\left(y_{i t} \mid x_{i t}, \alpha_{i}\right)=\alpha_{i} \exp \left(x_{i t}^{\prime} \beta\right)
$$

\footnotetext{
12 See Wooldridge (2002) for a discussion of Poisson models and estimation methods.

${ }^{13}$ To estimate the model, we used the QML Poisson fixed effects STATA routine by Tim Simcoe, University of Toronto.
} 
where $\alpha_{i}$ denotes the individual-specific effect. Hence, eq. (1) disentangles the influence of the vector of covariates $x^{\prime}$ it from unobserved researcher-specific skills that may cause differences in average publication productivity. Note that individual specific attributes of the professor, such as gender and field, are not included in the specification. Those are absorbed by the individual-specific effect as they typically do not change over time. In the pooled cross-section QML estimation, we implicitly assume that $\alpha_{i}=\alpha_{0}$ for all $i$.

The regression results for publications per year are shown in Table $2 .{ }^{14}$ Note that the academic entrepreneur (AE) coefficients show the difference in annual publications between faculty members who found or join firms and their NIH academic peers, all else constant. Looking at Model I, the coefficient estimate on $A E_{-} I N$ is positive and significant indicating that academic entrepreneurs publish more journal articles per year relative to their NIH peers. The marginal effect of $A E \_I N$ shows the academic entrepreneurs publish $23 \%$ [ $=\exp (0.208)-$ 1] more papers, on average. The coefficient estimate on $A E \_O U T$ is negative and significant indicating that academic entrepreneurs publish less than their NIH peers after founding or joining a for-profit firm. The marginal effect of $A E \_O U T$ shows the academic entrepreneurs publish an average of 32\% [= exp(-0.381)-1] less than their NIH peers after founding or joining a firm.

Model II breaks the group academic entrepreneurs into the three different employment transition states: those who stayed in the private sector permanently ( $\left.A E \_P E R M\right)$, those who returned to the university $\left(A E \_T E M P\right)$, and those whose subsequent employment could not be determined (AE_UNKNOWN). For those AEs who leave academe permanently, their publication productivity drops dramatically: the coefficient estimate of 0.792 represents a marginal effect of 55\% less publications per year than their NIH peers in academe. Interestingly, relative to their NIH peers, there is no statistically significant

\footnotetext{
${ }^{14}$ We used fourteen biannual time dummies in all models for consistency. The fixed-effects models did not converge with annual time dummies.
} 
difference in journal publication productivity for those academic entrepreneurs who eventually return, as seen by looking at the results for the coefficient on AE_TEMP. Note, however, that they publish less when compared to their previous performance as indicated by the positively significant coefficient on $A E \_I N$. For the academic entrepreneurs for whom we are uncertain about their final employment status, we find an effect similar to that of the permanent leavers. On average, their publication productivity is $47 \%$ less than their NIH peers.

Table 2: QML Poisson regressions on annual publication counts $(N=10,824)$

\begin{tabular}{|c|c|c|c|c|}
\hline \multirow[b]{2}{*}{ Variable } & \multicolumn{2}{|c|}{$\begin{array}{l}\text { Pooled cross-sectional } \\
\text { QML Poisson }\end{array}$} & \multicolumn{2}{|c|}{ Fixed effects panel QML Poisson } \\
\hline & Model I & Model II & Model III & Model IV \\
\hline$A E \_I N$ & $\begin{array}{l}0.208 * * \\
(0.099)\end{array}$ & $\begin{array}{l}0.207 * * \\
(0.098)\end{array}$ & & \\
\hline$A E \_O U T$ & $\begin{array}{l}-0.381 * * * \\
(0.145)\end{array}$ & & $\begin{array}{l}-0.532 * * * \\
(0.123)\end{array}$ & \\
\hline$A E \_P E R M$ & & $\begin{array}{l}-0.792 * * * \\
(0.200)\end{array}$ & & $\begin{array}{l}-1.040 * * * \\
(0.230)\end{array}$ \\
\hline$A E \_T E M P$ & & $\begin{array}{r}0.043 \\
(0.199)\end{array}$ & & $\begin{array}{l}-0.301 * * \\
(0.154)\end{array}$ \\
\hline$A E \_U N K N O W N$ & & $\begin{array}{l}-0.643^{* * * *} \\
(0.237)\end{array}$ & & $\begin{array}{l}-0.479 * * * \\
(0.238)\end{array}$ \\
\hline CAREER AGE & $\begin{array}{l}0.086 * * * \\
(0.010)\end{array}$ & $\begin{array}{l}0.087^{* * *} \\
(0.010)\end{array}$ & $\begin{array}{l}0.105^{* * *} \\
(0.018)\end{array}$ & $\begin{array}{l}0.106^{* * * *} \\
(0.018)\end{array}$ \\
\hline$(C A R E E R \text { AGE })^{2}$ & $\begin{array}{l}-0.002 * * * \\
(0.0001)\end{array}$ & $\begin{array}{l}-0.002^{* * *} \\
(0.0001)\end{array}$ & $\begin{array}{l}-0.002 * * * \\
(0.0001)\end{array}$ & $\begin{array}{l}-0.002 * * * \\
(0.0001)\end{array}$ \\
\hline Intercept & $\begin{array}{r}0.011 \\
(0.088) \\
\end{array}$ & $\begin{array}{r}0.010 \\
(0.088) \\
\end{array}$ & & \\
\hline $\begin{array}{l}\text { Joint significance of } 14 \text { time } \\
\text { dummies }\end{array}$ & $\chi^{2}(14)=19.18$ & $\chi^{2}(14)=19.36$ & $\chi^{2}(14)=19.54$ & $\chi^{2}(14)=19.83$ \\
\hline $\begin{array}{l}\text { Log-Likelihood } \\
\text { McFadden } \mathrm{R}^{2}\end{array}$ & $\begin{array}{l}-24,920.62 \\
0.022\end{array}$ & $\begin{array}{l}-24,800.76 \\
0.027\end{array}$ & $\begin{array}{c}-16,641.84 \\
0.347\end{array}$ & $\begin{array}{c}-16,602.87 \\
0.349\end{array}$ \\
\hline
\end{tabular}

Notes: $* * *(* *, *)$ indicate a significance level of $1 \%(5,10 \%)$.

The career age variables are also highly significant in the regressions, and yield an inverse u-shape as expected based on the existing literature studying scientists’ life cycle productivity. In terms of publication counts per year, the average profile suggests an NIH supported biomedical researcher’s productivity peaks at 21 years after obtaining a Ph.D. or M.D. degree, all else constant. 
We conducted further robustness checks on the pooled cross-sectional models. The life cycle productivity literature suggests that academic productivity may also be affected by cohort effects in addition to time and age effects (see, for instance, the discussion in Hall et al., 2007). We tested this by the inclusion of five cohort dummies based on the scientists' degree year, but these variables were always jointly insignificant. Therefore, we omit a detailed presentation. Furthermore, we added several other scientist characteristics, such as gender, degree type (Ph.D. or M.D.), degree obtained at public vs. private institution, degree field (biology, chemistry, or health sciences), degree obtained with the U.S. vs. foreign institution (see e.g. Toole and Czarnitzki, 2008, for a detailed description). Including these covariates did not significantly affect the results discussed above. For this reason, and the fact that all these characteristics are time-constant and drop out of the fixed effects panel regressions, we also omit a detailed presentation of these results.

The fixed effects QML Poisson regression results for annual journal publications are presented in rightmost columns of Table 2. In these models, the interpretation of the coefficient estimates is different than in the pooled models. The AE coefficients now measure the within scientist change in annual journal publications. The explanatory variable $A E \_I N$ does not appear in these models because it would be perfectly collinear with AE_OUT, its complement. Looking at Model III, the coefficient estimate on AE_OUT is negative and significant. After faculty entrepreneurs found or join for-profit firms, their journal publication productivity drops $40 \%$ relative to its pre-entrepreneurship level.

Model IV breaks the group academic entrepreneurs into the three different career patterns. For those scientists who leave academe permanently, their publication productivity drops dramatically: the coefficient estimate of -1.040 represents a marginal effect of $61 \%$ less publications per year relative to their productivity in academe. Those academic entrepreneurs who eventually return to academe also have significantly lower scholarly 
productivity after their experience founding or working at a for-profit firm. The coefficient estimate on $A E \_T E M P$ implies their average annual journal publications fall by $20 \%$. Even with this fall in productivity, the pooled cross-sectional results described above indicated these scientists publish as well as their non-entrepreneurial NIH peers after their entrepreneurial experience. The journal publication productivity for those academic entrepreneurs whose ultimate employment is unknown drops by $37 \%$.

When controlling for scientist-specific effects, the estimated career publication peak is slightly longer than in the pooled cross-sectional models, 25 career years rather than 21 years. Furthermore, a test on the presence of scientist-specific effects clearly rejects the assumption that $\alpha_{i}=\alpha_{0}$ for all $i$. This can also be seen easily in McFadden's $R^{2}$ measures presented in the tables. It jumps from 0.01 in the pooled cross-sectional models to 0.15 in the panel models.

\subsection{Weighted Journal Publications Per Year}

Our second measure of scholarly productivity is journal publications per year divided by the number of coauthors. Aside from this change in the dependent variable, the model specifications we examined are the same as above. To accommodate the new "fractional count” dependent variable, we estimated Tobit models where we consider zero publications as left censoring of the distribution. In the pooled cross-sectional model, we again calculated clustered standard errors which account for the panel structure of the data by allowing the error terms of the same scientist's observations in different periods to be correlated. For the panel model, we estimated a random effects Tobit model accounting for unobserved heterogeneity, such that

$$
y_{i t}^{*}=\beta_{0}+x_{i t}^{\prime} \beta+\mu_{i}+\varepsilon_{i t},
$$

where $\mu_{\mathrm{i}}$ refers to the scientist-specific effect and $\varepsilon_{\mathrm{it}}$ to the random error term (see e.g. Wooldridge, 2002, for technical details). We observe 


$$
y_{i t}=\left\{\begin{array}{l}
y_{i t}^{*} \text { if } \beta_{0}+x_{i t}^{\prime} \beta+\mu_{i}+\varepsilon_{i t}>0 \\
0 \quad \text { otherwise }
\end{array}\right.
$$

Note that there is no consistent Tobit fixed effects panel maximum likelihood estimator (see e.g. Cameron and Trivedi, 2005). Table 3 displays the regression results. Since the qualitative results described above continue to hold, we will not repeat a detailed discussion of these findings.

Table 3: Tobit models on weighted publication counts by number of co-authors $(N=10,824)$

Pooled cross-sectional Tobit

Variable

AE_IN

AE_OUT

AE_PERM

AE_TEMP

AE_UNKNOWN

(CAREER AGE) $)^{2}$

Intercept

Joint significance of 14 time dummies

Log-Likelihood

McFadden $\mathrm{R}^{2}$

$(0.144)$

0.018

$(0.194)$

$(0.223)$

$(0.010)$

$(0.010)$

(0.0001)

(0.0001)

(0.086)

$(0.085)$
Random effects panel Tobit

Model VII Model VIII

$\begin{array}{lcl}\text { Model V } & \text { Model VI } & \text { Model VII } \\ 0.209 * * & 0.207^{* *} & \\ (0.096) & (0.096) & \\ -0.417^{* * *} & & -0.514^{* * *} \\ (0.127) & & (0.049)\end{array}$

$-0.762 * * *$

$-0.945 * * *$

$(0.082)$

$-0.222 * * *$

(0.081)

$-0.592 * * *$

$-0.456 * * *$

$(0.089)$

$0.079 * * *$

$0.072 * * *$

$0.071 * * *$

(0.018)

$(0.007)$

$-0.002 * * *$

$0.007^{* * *}$

$-0.002 * * *$

(0.0001)

$(0.0001)$

$-0.141 *$

$-0.101$

$-0.108$

$(0.080)$

$(0.081)$

$\begin{array}{cccc}\chi^{2}(14)=16.22 & \chi^{2}(14)=16.33 & \chi^{2}(14)=14.87 & \chi^{2}(14)=14.57 \\ -14,128.66 & -14,093.11 & -12,167.05 & -12,145.55 \\ 0.011 & 0.013 & 0.148 & 0.150\end{array}$

Notes: $* * *(* *, *)$ indicate a significance level of $1 \%(5,10 \%)$.

It is noteworthy, however, that all the multivariate regression results show that scholarly productivity falls for those biomedical scientists who return to academe after founding or joining a for-profit firm. The simple descriptive statistics suggested the opposite effect, but it does not hold up when career age and scientist unobserved heterogeneity are taken into account. Unfortunately, our data do not allow us to observe the post- 
commercialization activities of these individuals, but the results imply that the experience of founding or joining a for-profit firm has a lasting influence on journal publications. This must reflect some new influences on how these faculty members allocate their time, cognitive effort, and/or commitments.

\subsection{Robustness test: Duration of Private Sector Experience}

An alternative to the dummy variable modeling of the employment transition is to use a measure of the elapsed time spent outside the non-for-profit research sector. We calculated a variable called AE_YEARS_OUT that measures the cumulative number of years an academic entrepreneur is in the private sector. Given the panel structure of the data, this variable increases by one as for each additional year outside academe. This variable only applies to academic entrepreneurs whose ultimate disposition in known (by us), the AE_TEMP and AE_PERM groups. For those academic entrepreneurs who return to academe, we calculated the aggregate duration of all their SBIR projects. For those scientists whose switch is permanent, the value of the variable is the remaining time in their working careers (recall we assume a scientist's working career is 35 years after the date of their advanced degree). For the group of switching scientists whose disposition is unknown, we kept the original dummy variable formulation because we do not know if these scientists returned or not. Finally, we created a new dummy variable, $A E \_B A C K$, that indicates the scientist returned to academe. Holding constant the time spent in the private sector, this dummy variable captures how publication productivity changes (before versus after) for the group of scientists who switch temporarily to the private sector.

The results for both publications per year and weighted publications per year are presented in Table 4. Overall, the results are similar to those obtained using the dummy variable formulation. The coefficient estimate for the new explanatory variable, AE_YEARS_OUT, is negative and significant. To illustrate the marginal effect of this 
continuous covariate, Figure 3 plots the expected number of journal publications based on the results found using the conditional fixed effects Poisson regression. The marginal effect of AE_YEARS_OUT is the slope of this curve. It shows that the loss in academic productivity is highest in the first years and then gradually declines over time.

Holding constant the amount of time spent in the private sector, scholarly productivity declines for those AEs who return to academe after founding or joining a for-profit firm. In the pooled regressions, $A E \_B A C K$ is insignificant and indicates that their postcommercialization productivity is not significantly different from their NIH peers. However, since the $A E \_I N$ variable is positive and significant, they are less productive than before. The panel data models confirm this result. In those models, $A E \_B A C K$ is negative and significant.

Table 4: QML Poisson and Tobit regressions on publication counts $(N=10,824)$

\begin{tabular}{|c|c|c|c|c|}
\hline \multirow[b]{2}{*}{ Variable } & \multicolumn{2}{|c|}{$\begin{array}{l}\text { Poisson models on } \\
\text { publication counts }\end{array}$} & \multicolumn{2}{|c|}{$\begin{array}{l}\text { Tobit models on weighted } \\
\text { publication counts }\end{array}$} \\
\hline & $\begin{array}{c}\text { Pooled cross- } \\
\text { sectional model } \\
\text { with clustered } \\
\text { std. errors } \\
\end{array}$ & $\begin{array}{l}\text { Fixed effects } \\
\text { model with fully } \\
\text { robust std. errors }\end{array}$ & $\begin{array}{c}\text { Pooled cross- } \\
\text { sectional model } \\
\text { with clustered } \\
\text { std. errors } \\
\end{array}$ & $\begin{array}{l}\text { Random-effects } \\
\text { panel model }\end{array}$ \\
\hline$A E \_I N$ & $\begin{array}{l}0.208^{* *} \\
(0.097)\end{array}$ & & $\begin{array}{l}0.211^{* *} \\
(0.095)\end{array}$ & \\
\hline AE_YEARS_OUT & $\begin{array}{l}-0.116 * * * \\
(0.021)\end{array}$ & $\begin{array}{l}-0.161 * * * \\
(0.023)\end{array}$ & $\begin{array}{l}-0.101 * * * \\
(0.015)\end{array}$ & $\begin{array}{l}-0.117 * * * \\
(0.009)\end{array}$ \\
\hline$A E_{-} B A C K$ & $\begin{array}{r}-0.071 \\
(0.234)\end{array}$ & $\begin{array}{l}-0.438 * * \\
(0.173)\end{array}$ & $\begin{array}{r}-0.126 \\
(0.213)\end{array}$ & $\begin{array}{l}-0.377 * * * \\
(0.081)\end{array}$ \\
\hline$A E \_U N K N O W N$ & $\begin{array}{l}-0.658 * * * \\
(0.236)\end{array}$ & $\begin{array}{l}-0.501^{* *} \\
(0.238)\end{array}$ & $\begin{array}{l}-0.609 * * * \\
(0.222)\end{array}$ & $\begin{array}{l}-0.475^{* * *} \\
(0.089)\end{array}$ \\
\hline CAREER AGE & $\begin{array}{l}0.086^{* * *} \\
(0.010)\end{array}$ & $\begin{array}{l}0.106 * * * \\
(0.238)\end{array}$ & $\begin{array}{l}0.078^{* * *} \\
(0.010)\end{array}$ & $\begin{array}{l}0.070^{* * *} \\
(0.008)\end{array}$ \\
\hline$(C A R E E R \text { AGE })^{2}$ & $\begin{array}{l}-0.002 * * * \\
(0.0003)\end{array}$ & $\begin{array}{l}-0.002 * * * \\
(0.0003)\end{array}$ & $\begin{array}{l}-0.002 * * * \\
(0.0003)\end{array}$ & $\begin{array}{l}-0.002^{* * *} \\
(0.0001)\end{array}$ \\
\hline Intercept & $\begin{array}{r}0.009 \\
(0.088) \\
\end{array}$ & & $\begin{array}{r}-0.138 \\
(0.086) \\
\end{array}$ & $\begin{array}{r}-0.983 \\
(0.080) \\
\end{array}$ \\
\hline $\begin{array}{l}\text { Joint significance of } 14 \text { time } \\
\text { dummies }\end{array}$ & $\chi^{2}(14)=19.64$ & $\chi^{2}(14)=19.98$ & $\chi^{2}(14)=16.16$ & $\chi^{2}(14)=13.37$ \\
\hline Log-Likelihood & $-24,734.54$ & $-16,505.41$ & $-14,072.52$ & $-12,114.48$ \\
\hline McFadden $\mathrm{R}^{2}$ & 0.029 & 0.352 & 0.015 & 0.152 \\
\hline
\end{tabular}


Figure 3: Expected value of publications as a function of years out of academe

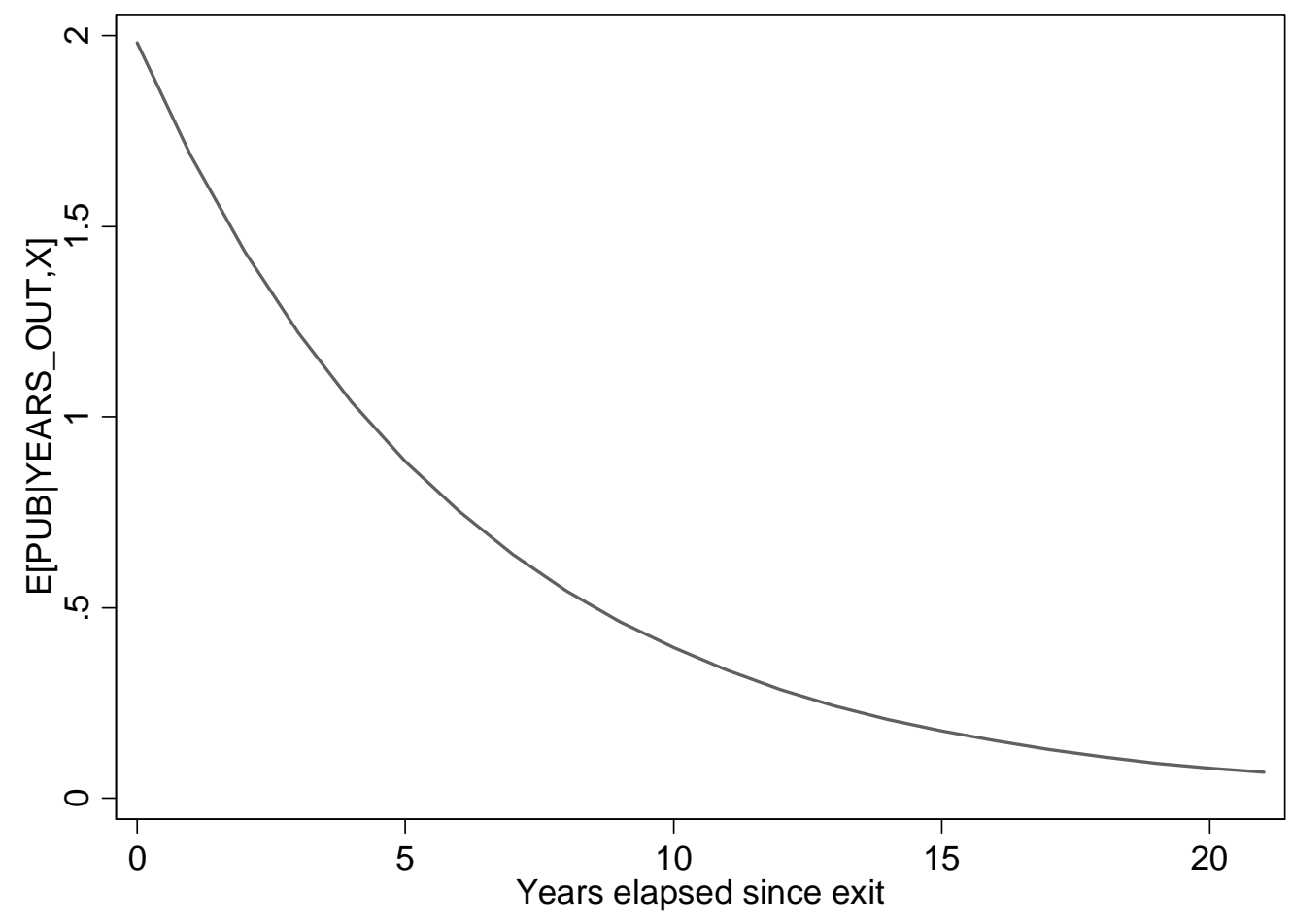

Note: This graph shows the expected number of publications as a function of the years elapsed since exit from academe. These are based on the results from the conditional fixed effects Poisson model seen in Table 4 with all other covariates fixed at their sample averages. The marginal effect of AE_YEARS_OUT is the slope of this curve.

\section{Conclusions}

Our empirical analysis of NIH supported biomedical academic scientists indicates a trade-off exists between the production of public scientific knowledge and faculty entrepreneurship when faculty members found or join a for-profit firm. This finding is important for a couple of reasons. First, to the extent that the stock of public scientific knowledge is a critical source of opportunities contributing to long-run economic growth, it suggests that many of the recent efforts to foster university technology transfer through faculty spin-off creation may be short-sided policy efforts that ultimately undermine long-run growth potential. While the jury is still out, this possibility deserves additional research and policymakers at all levels should be aware of this trade-off. Second, even though founding or joining a for-profit firm is among the most extreme forms of faculty entrepreneurship, the 
number of university faculty spin-offs is growing annually based on data collected by the Association of University Technology Managers (AUTM). In our earlier paper (Toole and Czarnitzki, 2008), we argued that the aggregate loss to public scientific knowledge from these extreme forms of faculty entrepreneurship is substantial. In any case, our findings highlight an important (yet unanswered) question: what is the appropriate balance between fostering faculty spin-offs and protecting traditional faculty roles such as research and teaching?

One of the unique contributions of this paper was to examine how permanent versus temporary employment transitions to for-profit firms affect individual-level academic research productivity. For the group of NIH supported biomedical academic entrepreneurs (AEs) who returned to academe, we found their scholarly productivity was lower after they returned. Prior to founding or joining a for-profit firm, these AEs were more productive than the randomly selected control group of NIH research peers, but after they returned, their scholarly productivity was not significantly different from the control group. Further, when accounting for unobserved scientist heterogeneity using panel data methods, these returning AEs published significantly less than they had published prior to their entrepreneurial experiences. The "fertile pasture" idea that suggests engaging with the private sector augments the academic scientist's scholarly fecundity is not supported by our data. But why aren't these academic entrepreneurs who venture only temporarily into the private sector able to achieve the same level of scholarly productivity that they had before? Unfortunately, our data are not detailed enough to answer this follow-on question. We surmise that the AE's interest in commercialization does not end upon their return to academe. It is possible they still devote their time and cognitive effort to non-publication objectives and, perhaps, they maintain strong commitments outside the non-for-profit research sector. In any event, better data are needed before we can shed more light on this issue. 
Our findings are consistent with Buenstorf (2009) who found that both publications and citations fell after German scholars at the Max Planck Institute became founders of spinoff companies. Our findings are not consistent with Zucker and Darby (2007), however, they only had twelve "affiliated" star scientists who founded or joined a for-profit firm in their sample. Finally, Lowe and Gonzalez-Brambila (2007) did not find any statistically significant change in scholarly productivity for their sample of medicine/biology and chemistry academic entrepreneurs. One important aspect of their sample, however, is that all of their academic entrepreneurs maintained full-time positions at their universities. Data limitations prevent us from knowing how involved those scientists were with their firms. In contrast, from our SBIR data, we know the AEs we studied devoted significant effort to the firm. Quite generally, the literature suggests that academic fields are quite different. It could be seriously misleading to general our findings for NIH supported biomedical academic entrepreneurs to entrepreneurial faculty in other fields such as engineering.

Without a doubt, much more research is needed to help build our understanding of the relationship between faculty entrepreneurship and scholarly productivity. As was pointed out in the literature review section, there are a spectrum of faculty entrepreneurial behaviors that differ in the degree to which they require a faculty member's time, cognitive effort, and his or her commitment to stakeholders outside the not-for-profit research sector. More theoretical and empirical work is needed to help delineate these behaviors. It almost goes without saying that our measures of scholarly productivity are limited and, for lack of data, we could not include journal article citations in this analysis. Interestingly, for faculty patenting in Germany, Czarnitzki et al. (2009) find that co-patenting with industry shows weak negative effects on publication counts, but stronger negative effects on publication quality measured through both journal impact factor weighted publication counts and the number of forward citations. Furthermore, as was pointed out in the beginning of our data section, there is a 
serious paucity of data identifying the population of academic scientists and tracking the various entrepreneurial behaviors. We rely on the U.S. SBIR program to provide systematic data, but this is not nearly as comprehensive as we would like. For instance, data on the specific tasks performed by academic entrepreneurs at the firm along with details of their employment contracts would help to understand how responsibilities and commitments affect their allocation of time and effort across the boundary between the for-profit and not-forprofit sectors. 


\section{References}

Azoulay, P., W. Ding, and T. Stuart (2006), The effect of academic patenting on (public) research output, NBER Working Paper No. 11917, Cambridge, MA. (Forthcoming in the Journal of Industrial Economics)

Azoulay, P., A. Stellman, and J.G. Zivin (2006), PublicationHarvester: An open-source software tool for science policy research, Research Policy 35(7), 970-974.

Breschi, S., F. Lissoni, and F. Montobbio (2008), University patenting and scientific productivity: a quantitative study of Italian academic inventors, European Management Review 5, 91-109.

Buenstorf, G. (2009), Is commercialization good or bad for science? Individual-level evidence from the Max Planck Society, Research Policy, 38, 281-292.

Cameron, A.C. and P.K. Trivedi (2005), Microeconometrics: Methods and Applications, New York: Cambridge University Press.

Czarnitzki, D., W. Glänzel and K. Hussinger (2009), Heterogeneity of Patenting Activity and Its Implications for Scientific Research, Research Policy 38(1), 26-34.

Diamond, A.M. (1986), The life-cycle research productivity of mathematicians and scientists, Journal of Gerontology 41(4), 520-525.

Hall, B.H., J. Mairesse, and L. Turner (2007), Identifying age, cohort and period effects in scientific research productivity: Discussion and illustration using simulated and actual data on French physicists, Economics of Innovation and New Technology 16(2), 159177.

Gittelman, M., and B. Kogut (2003), Does Good Science Lead to Valuable Knowledge? Biotechnology Firms and the Evolutionary Logic of Citation Patterns, Management Science 49(4), 366-382.

Goldfarb, B., G. Marschke, and A. Smith (2009), Scholarship and Inventive Activity in the University: Complements or Substitutes?, Economics of Innovation and New Technology, forthcoming. 
Levin, S.G., and P.E. Stephan (1991), Research Productivity over the life cycle: Evidence for academic scientists, American Economic Review 81(1), 114-132.

Louis, K.S., D. Blumenthal, M.E. Gluck, and M.A. Stoto (1989), Entrepreneurs in Academe: An exploration of Behaviors among life scientists, Administrative Science Quarterly 34, 110-131.

Lowe, R.A., and C. Gonzalez-Brambila (2007), Faculty entrepreneurs and research productivity, Journal of Technology Transfer 32, 173-194.

Stern, S. (2004), Do scientist pay to be scientists? Management Science 50(6), 835-853.

Stuart, T., and W. Ding (2006), When do scientists become entrepreneurs: The social structural antecedents of commercial activity in the academic life sciences, American Journal of Sociology, 110(1), 97-144.

Toole, A.A., and D. Czarnitzki (2007), Biomedical academic entrepreneurship through the SBIR program, Journal of Economic Behavior \& Organization 63, 716-738.

Toole, A.A. and D. Czarnitzki (2008), Commercializing science: is there a university "brain drain” from academic entrepreneurship? unpublished manuscript, New Brunswick, NJ, and Leuven.

Toole, A.A., and D. Czarnitzki (2009), Exploring the relationship between scientist human capital and firm performance: the case of biomedical academic entrepreneurs in the SBIR program, Management Science 55(1), 101-114.

Wooldridge, J.M. (2002), Econometric Analysis of Cross Section and Panel Data, Cambridge, MA: The MIT Press.

Zucker, L.G., and M.R. Darby (2007), Virtuous circles in science and commerce, Papers in Regional Science 86(3), 445-470. 